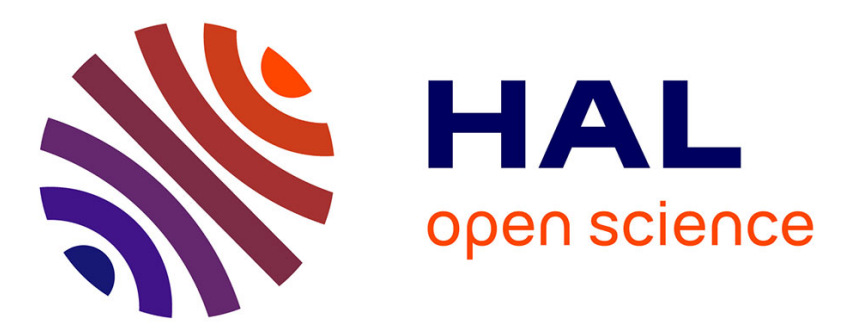

\title{
A Compact Wideband High Power Amplifier in GaN Technology with $47 \%$ peak PAE
}

Victor Dupuy, Nathalie Deltimple, Eric Kerhervé, Jean-Philippe Plaze, Yves Mancuso, Patrick Garrec, Magalie Dematos, Sofiane Aloui

\section{To cite this version:}

Victor Dupuy, Nathalie Deltimple, Eric Kerhervé, Jean-Philippe Plaze, Yves Mancuso, et al.. A Compact Wideband High Power Amplifier in GaN Technology with 47\% peak PAE. IEEE IWS 2014, Mar 2014, China. hal-00991882

\section{HAL Id: hal-00991882 https://hal.science/hal-00991882}

Submitted on 16 May 2014

HAL is a multi-disciplinary open access archive for the deposit and dissemination of scientific research documents, whether they are published or not. The documents may come from teaching and research institutions in France or abroad, or from public or private research centers.
L'archive ouverte pluridisciplinaire HAL, est destinée au dépôt et à la diffusion de documents scientifiques de niveau recherche, publiés ou non, émanant des établissements d'enseignement et de recherche français ou étrangers, des laboratoires publics ou privés. 


\title{
A Compact Wideband High Power Amplifier in GaN Technology with $47 \%$ peak PAE
}

\author{
Victor Dupuy ${ }^{1}$, Nathalie Deltimple ${ }^{1}$, Eric Kerhervé ${ }^{1,}{ }^{1}$ ean-Philippe Plaze ${ }^{2}$, \\ Yves Mancuso $^{2}$, Patrick Garrec ${ }^{3}$, Magali Dematos ${ }^{1}$ and Sofiane Aloui ${ }^{1}$ \\ ${ }^{1}$ University of Bordeaux, IMS Lab, UMR 5218, IPB, $351 \mathrm{crs}$ de la liberation 33405 Talence, France \\ ${ }^{2}$ Thales Systèmes Aéroportés, 2 avenue Gay Lussac 78990 Elancourt, France \\ ${ }^{3}$ Thales Systèmes Aéroportés, 25 avenue Gustave Eiffel 33608 Pessac, France
}

victor.dupuy@ims-bordeaux.fr

\begin{abstract}
This article presents a 4-6GHz power amplifier in a $0.25 \mu \mathrm{m}$ GaN integrated technology from UMS foundry. Two unit power cells are combined to increase output power. A new power combiner based on a stacked balun is presented. It has the advantage of occupying a much smaller area than a conventional one. The measured circuit exhibits a peak output power of $37 \mathrm{dBm}$ together with a peak PAE of $47 \%$ at $4 \mathrm{GHz}$.
\end{abstract}

Index Terms - GaN. High power amplifier (HPA), power combining, vertically stacked balun.

\section{INTRODUCTION}

One of the main advantages of GaN based integrated technologies is the ability to deliver a high output power over a wide frequency range. Various applications can take advantage of this property such as electronic warfare communications and radar systems. For example, radars in $\mathrm{S}, \mathrm{C}, \mathrm{X}$ and $\mathrm{Ku}$ bands for military applications or meteorological radars in $\mathrm{C}$-band and base stations for cellular phones can be mentioned. Usually to increase the delivered power from the emitter side, a solution is to parallelize unit power cells in the power amplifier (PA) [1], [2]. In MMICs, power combining is generally achieved through current combination [3]. This approach exhibits good performances in terms of efficiency at the expense of an important occupied area. The MMIC stacked balun approach allows reducing drastically the combiner size while keeping efficiency performances. The MMIC vertically stacked balun concept is introduced in [4].

This chip has been realized within the SIMCLAIRS competed program, a European consortium. For characterization matters required in the consortium, the power amplifier is voluntary unmatched in the input because it is meant to be driven by a separated driver stage. With proper matching, this chip achieve much larger bandwidth performances from. This circuit has been implemented in the $\mathrm{GH} 25$ integrated GaN process from UMS foundry. Power devices are HEMT $0.25 \mu \mathrm{m}$ transistors. This technology node permits to deliver high output power up to $20 \mathrm{GHz}$.
Section 2 will focus on the amplifier architecture and the innovative power combiner design. In section 3 measurement results will be presented for both linear and non-linear behavior and section 4 will present simulation results of a $\mathrm{C}$ to $\mathrm{X}$-band high power amplifier (HPA) based on the same topology. To the author's knowledge this circuit is the first demonstrator of a HPA MMIC using a stacked balun as a power combiner.

\section{ARCHITECTURE}

\section{A. HPA structure}

For power enhancement, a differential structure has been adopted. The electrical schematic of the realized HPA is presented in Fig. 1. The unit power cell is made of a GaN HEMT of $8 * 125 \mu \mathrm{m}$ resulting in a total gate width of $1 \mathrm{~mm}$. A stabilization network made off a serial RC network $(R, C)$ is placed on the transistor gate to avoid low frequency self-oscillation. Each cell is biased directly through the inductor $L_{b}$. $C_{b p}$ acts as a by pass capacitor to cut the DC component. Both cells are recombined out of phase in the stacked balun, which perform the differential to single mode conversion. This balun is used in the marchand configuration (the termination of the secondary is left open). Unit cells receive their supply through the balun middle point.

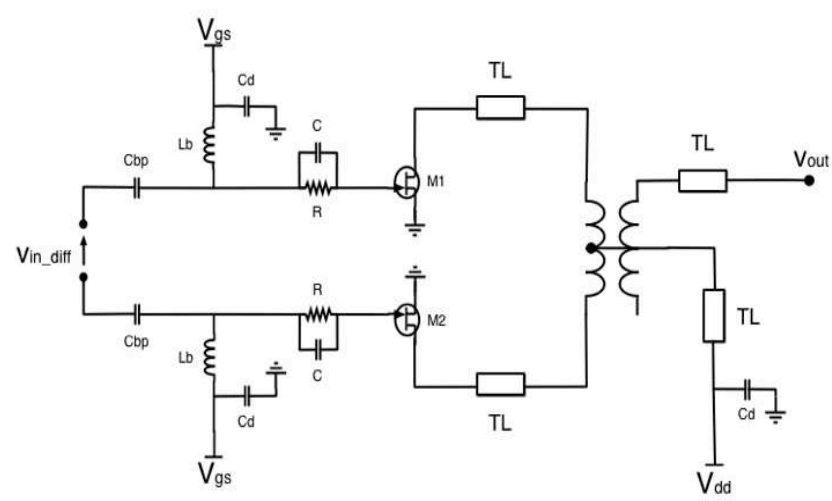

Fig. 1. Differential to single power amplifier architecture 
The supply is set to $25 \mathrm{~V}$ and the gate bias is adjusted in order to achieve a DC current consumption of $80 \mathrm{~mA} / \mathrm{mm}$; this results in a total DC power consumption of $4 \mathrm{~W}$ for the entire HPA. This biasing value has been selected to both respect the founder recommendations for reliability, be able to deliver $5 \mathrm{~W}$ of output power, and achieve best efficiency possible.

\section{B. Power combiner design}

The power combiner is typically the component that occupies the larger die area in an MMIC HPA. In this design, a vertically stacked balun is introduced here to act as a power combiner. By stacking both windings instead of putting them on a same layer, the occupied area is drastically reduced. Power transfer is then made through vertical coupling. The stacked balun has been optimized to have minimal insertion loss in the frequency band of interest. The balun has been designed to be matched to power cells output optimal impedances without any matching network between the power cell and the balun. Theses optimal impedances have been obtained from load pull simulations at several frequency points. Electromagnetic simulations of the standalone balun performed with the Agilent Momentum software. The balun exhibits minimal insertion loss of $0.7 \mathrm{~dB}$ in the [4GHz-6GHz] band. It is mandatory that the balun is exactly symmetrical so both cells see the exact same impedances. Otherwise, one cell would drain more current than the other resulting in self-heating and destruction of this cell.

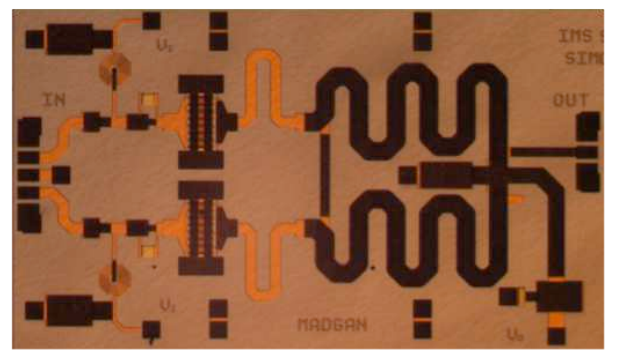

Fig. 2. Chip photography $(3.3 \mathrm{~mm} * 1.9 \mathrm{~mm})$

Fig. 2 is photography of the realized chip, it occupies an area of $6.27 \mathrm{~mm}^{2}$. In the next section, measurement results will be compared to simulation for both linear and nonlinear behavior.

\section{III.MEASURED PERFORMANCES}

The measured S-parameters are presented in Fig. 3 from $2 \mathrm{GHz}$ to $12 \mathrm{GHz}$. A peak gain of $11.2 \mathrm{~dB}$ is observed at $4 \mathrm{GHz}$ and the gain remains over $7.8 \mathrm{~dB}$ from $2.8 \mathrm{GHz}$ to $6 \mathrm{GHz}$. A low pass $\mathrm{RC}$ filter placed on each transistor gate to prevent low frequencies oscillation explains the strong gain decrease under $3 \mathrm{GHz}$.
$S_{22}$ and $S_{11}$ plots prove that the circuit is stable from a linear point of view, because they always of negative values. Moreover, K-factor has been checked to be over unity. Output matching has been optimized to increase output power and efficiency instead of small signal behavior.

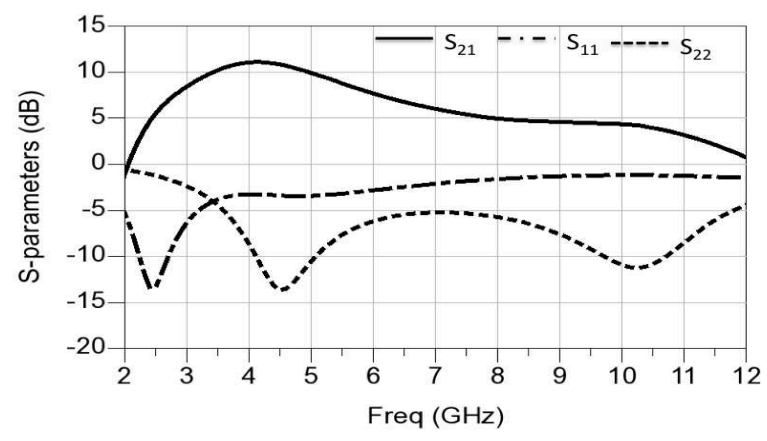

Fig. 3. Measured linear gain from $2 \mathrm{GHz}$ to $12 \mathrm{GHz}$

Non-linear measurements are presented in Fig. 4, 5 and 6; output power, PAE and gain are plotted respectively. For each plot 3 frequencies points are presented: $4 \mathrm{GHz}$, $5 \mathrm{GHz}$ and $6 \mathrm{GHz}$. Due to input power delivery limitations in the measurement setup, plots do not show output power saturation and thus the PAE decrease after reaching a maximum value. However, looking at output power curves, saturation is almost achieved so the PAE will not increase by more than $2 \%$. The HPA delivers $37 \mathrm{dBm}$, $35.2 \mathrm{dBm}$ and $33.5 \mathrm{dBm}$ at $4 \mathrm{GHz}, 5 \mathrm{GHz}$ and $6 \mathrm{GHz}$ respectively. For the same frequency points, maximum PAE values are $47 \%, 38 \%$ and $17.5 \%$. These results are in good agreement with simulation results. Table 1 summarizes measurement and simulations results for linear gain, output power, efficiency and power gain for an input power of $27 \mathrm{dBm}$.

This HPA occupies a reduced area of $6.27 \mathrm{~mm}^{2}$. This is an encouraging step towards HPA integration. Indeed, many HPA, found in literature [5] and [6], are capable to deliver more than $100 \mathrm{~W}$ of output power but they suffer from their size making them not suited for embedded applications.

TABLE I

COMPARISON BETWEEN MEASUREMENTS AND SIMULATIONS @ $\mathrm{P}_{\mathrm{IN}}=27 \mathrm{dBm}$

\begin{tabular}{|c|c|c|c|c|}
\hline & & $4 \mathrm{GHz}$ & $5 \mathrm{GHz}$ & $6 \mathrm{GHz}$ \\
\hline \multirow{2}{*}{$\mathrm{P}_{\text {out }}(\mathrm{dBm})$} & $\operatorname{sim}$ & 36.6 & 35.3 & 33.5 \\
\hline & meas & 37 & 35.2 & 33.5 \\
\hline \multirow{2}{*}{$\mathrm{PAE}(\%)$} & $\operatorname{sim}$ & 52 & 37 & 21 \\
\hline & meas & 47 & 38 & 17.5 \\
\hline \multirow{2}{*}{ Gain(dB) } & $\operatorname{sim}$ & 8.7 & 8.3 & 6.4 \\
\hline & meas & 9.2 & 7.4 & 6.2 \\
\hline
\end{tabular}




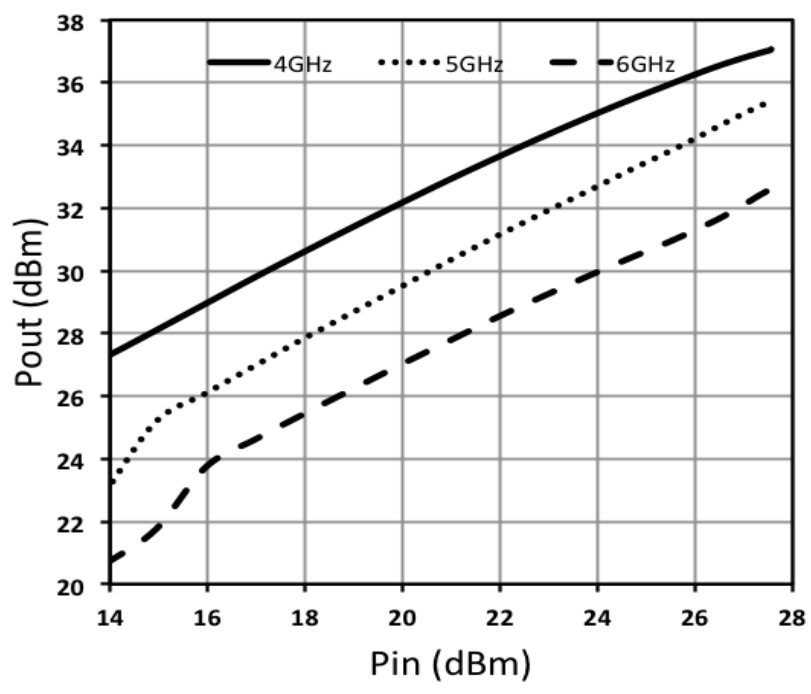

Fig. 4. Measured Pout vs. Pin @4GHz, 5GHz and 6GHz

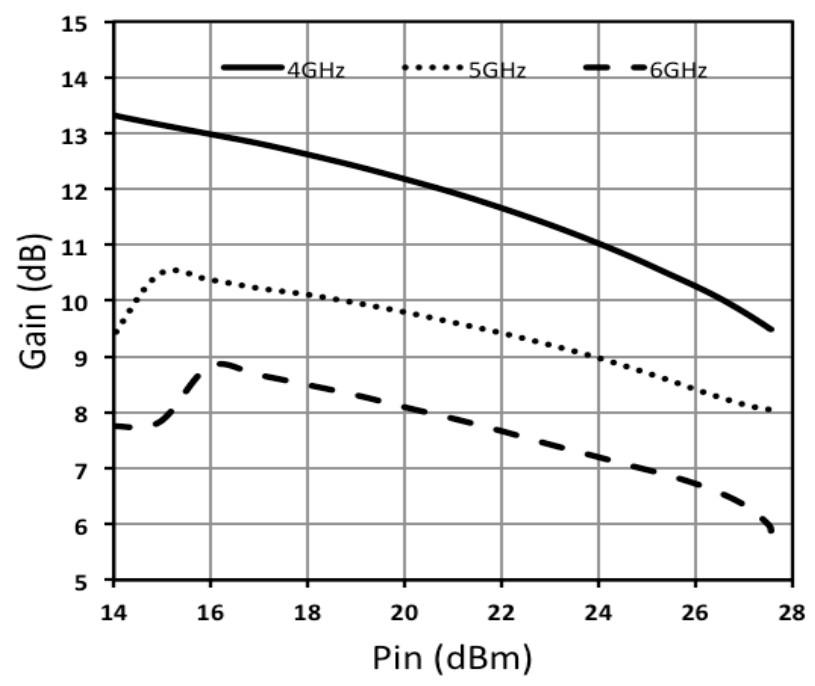

Fig. 5. Measured PAE vs. Pin @4GHz, $5 \mathrm{GHz}$ and $6 \mathrm{GHz}$

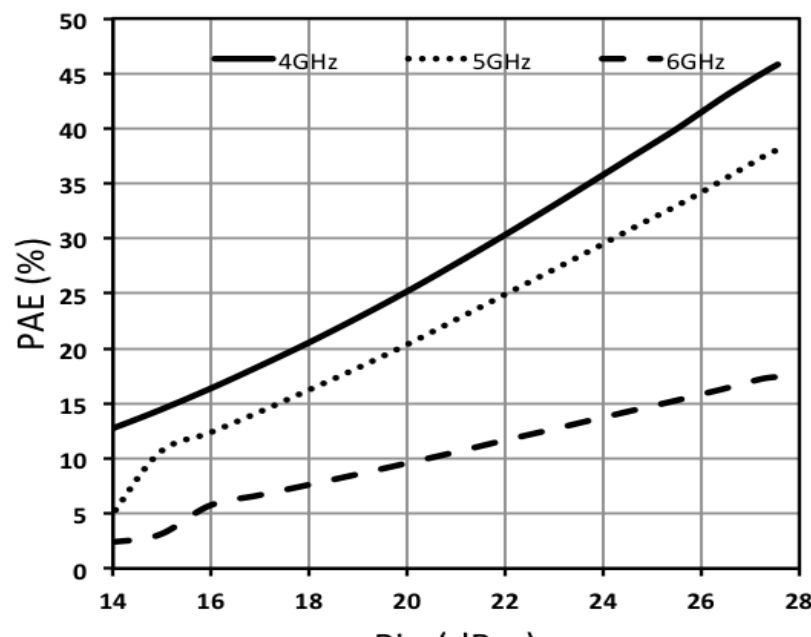

Fig. 6. Measured Gain vs. Pin $\left(\mathrm{dBg}_{4 \mathrm{GHz}}\right) 5 \mathrm{GHz}$ and $6 \mathrm{GHz}$

\section{IV . C-BAND TO X-BAND SIMULATED HPA}

As mentioned earlier, this HPA has been voluntary left unmatched in the input as it is meant to be driven by a preliminary stage. However to demonstrate the wideband abilities of this power stage, simulations with a matched input from $4 \mathrm{GHz}$ to $11 \mathrm{GHz}$ have been performed and are presented in the following. The demonstration of an innovative, compact and very efficient power combining technique has been done through measurements of the HPA presented in this article. In fact, the output balun can act as a low loss power combiner from $4 \mathrm{GHz}$ to $11 \mathrm{GHz}$, a frequency band in which it exhibits less than $1 \mathrm{~dB}$ of insertion loss. Non-linear simulations have been performed to evaluate output power, efficiency and gain performances from Cband to X-band. To simulate proper input matching, the input impedance has been swept from $50 \Omega$ at $4 \mathrm{GHz}$ to 5 $\Omega$ at $11 \mathrm{Ghz}$ as one would do performing source-pull on a single transistor expect it is done on the overall HPA here. Simulation is performed at Pin $=29 \mathrm{dBm}$ from $4 \mathrm{GHz}$ to $11 \mathrm{Ghz}$, results are plotted in Fig. 7.

In average, output power, PAE and associated gain respectively reach values of $35.5 \mathrm{dBm}, 34 \%$ and $6.5 \mathrm{~dB}$ over the full frequency range. From $8.5 \mathrm{GHz}$ to $10.5 \mathrm{GHz}$ an output power greater than $35 \mathrm{dBm}$ is achieved together with an efficiency higher than $30 \%$. The maximal efficiency reaches a value of $51 \%$ at $4.6 \mathrm{GHz}$.

These results validate the ability of such a topology to act as a C-band to X-band high efficiency HPA. Indeed, only source impedance has been swept to obtain results presented in Fig. 7, everything else in the circuit has not been changed and is exactly same as what shown in Fig.1 and detailed in sections 1,2 and 3 .

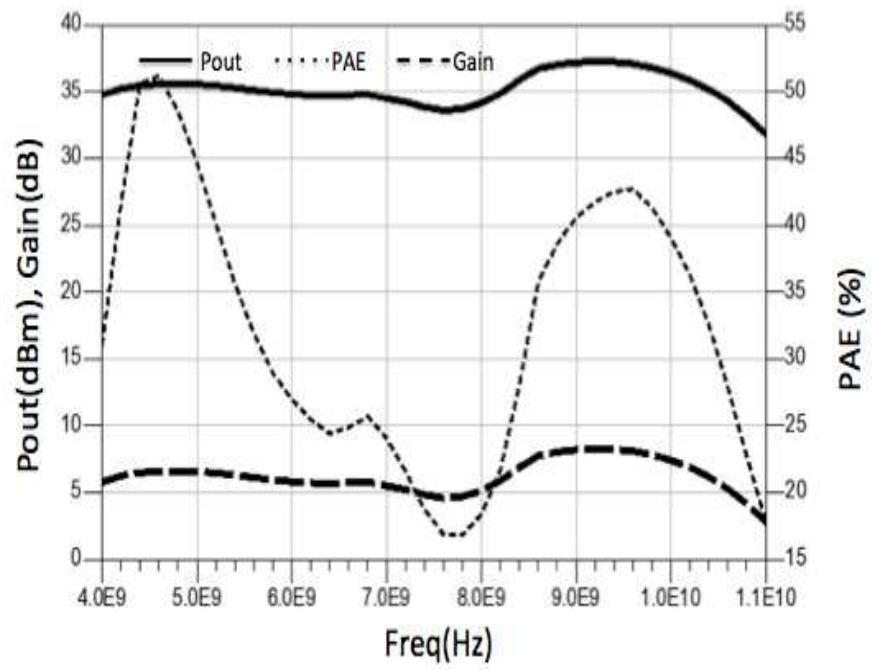

Fig. 7. Input matched Simulated Pout, PAE and Gain $@ P i n=29 \mathrm{dBm}$ 


\section{V.CONCLUSION}

The demonstration of an innovative, compact and very efficient power combining technique has been done through measurements of the HPA presented in this article. This opens the door to the realization of smaller size HPAs in the future. The realized HPA exhibits an output power of $5 \mathrm{~W}$ and a PAE of $47 \%$ at $4 \mathrm{GHz}$. The main perspective is to extend wideband performances of this HPA to target even more applications such as multi antennas communicating systems or electronic warfare. This has been demonstrated in section 4 where an average PAE of $34 \%$ from $4 \mathrm{GHz}$ to $11 \mathrm{GHz}$ is reported. Moreover, to increase output power too, the principle of the vertically stacked balun can be extended to parallelize more than 2 cells by connecting baluns in serial and realize a distributed active transformer (DAT). This open the door to the realization of C-band to X-band HPAs delivering more than 10 Watts with PAE greater than $30 \%$ with a drastically reduced die size compared to actual state of art.

\section{ACKNOWLEDGEMENT}

The present work has been led in the framework of the ITP SIMCLAIRS competed program. France, United Kingdom and Sweden have mandated the European Defense Agency (EDA) to contract the Project with a Consortium composed of THALES SYSTEMES
AEROPORTES France, acting as the Consortium Leader, SELEX Galileo Ltd, THALES UK Ltd and SAAB AB.

\section{REFERENCES}

[1] Demirel, N.; Kerherve, E.; Plana, R.; Pache, D.; "79GHz BiCMOS single-ended and differential power amplifiers," Microwave Integrated Circuits Conference (EuMIC), pp 1690 -1693, 2010.

[2] L. Leyssenne, E. Kerherve, Y. Deval, N. Deltimple, D. Belot, "A Novel WLAN Power Amplifier Adaptive Loop Based on Delta-Sigma Non-Linearity Control", IEEE Radio Week Symposium (RWS2009), San Diego, CA, United States, pp 594,597, Jan 16-23, 2009.

[3] Y Youngrak Park; Youngmin Kim; Wooyeol Choi; Jungrin Woo; Youngwoo Kwon, "X-to-K band broadband wattlevel power amplifier using stacked-FET unit cells," Radio Frequency Integrated Circuits Symposium (RFIC), 2011 IEEE, vol., no., pp.1,4, 5-7 June 2011.

[4] US PATENT 6476704, MILES E. GOFF, The Raytheon Company, MA (US).

[5] Yamasaki, T.; Kittaka, Y.; Minamide, H.; Yamauchi, K.; Miwa, S.; Goto, S.; Nakayama, M.; Kohno, M.; Yoshida, N., "A $68 \%$ efficiency, C-band $100 \mathrm{~W}$ GaN power amplifier for space applications," Microwave Symposium Digest (MTT), 2010 IEEE MTT-S International, vol., no., pp.1384,1387, 23-28 May 2010

[6] Yamanaka, K.; Mori, K.; Iyomasa, K.; Ohtsuka, H.; Noto, H.; Nakayama, M.; Kamo, Y.; Isota, Y., "C-band GaN HEMT Power Amplifier with 220W Output Power," Microwave Symposium, 2007. IEEE/MTT-S International, vol., no., pp.1251,1254, 3-8 June 2007 